\title{
NON-CANCER HUMAN HEALTH RISK ASSESSMENT FROM EXPOSURE TO HEAVY METALS IN SURFACE AND GROUNDWATER IN IGUN IJESHA, SOUTHWEST NIGERIA
}

\author{
${ }^{1}$ Ayantobo, O.O., ${ }^{1}$ J.A. Awomeso, ${ }^{1}$ G.O. Oluwasanya, ${ }^{2}$ B.S. Bada and ${ }^{2}$ A.M. Taiwo \\ ${ }^{1}$ Department of Water Resources Management and Agricultural-Meteorology, \\ Federal University of Agriculture, Abeokuta (FUNAAB), Nigeria \\ ${ }^{2}$ Department of Environmental Management and Toxicology, FUNAAB, Nigeria
}

Received 2014-02-15; Revised 2014-02-27; Accepted 2014-05-10

\begin{abstract}
Non-cancer hazard index for inhabitants exposed to heavy metals in surface and groundwater of the abandoned metal mine in Igun-Ijesha area were evaluated. A total of thirty-eight water samples were collected from surface and ground water sources in the study area between September 2012 and February 2013 and the concentrations of heavy metals were determined using Atomic Absorption Spectrophotometer. Non-cancer risk assessments from possible exposure to heavy metals were evaluated using the United States Environmental Protection Agency's human health risk assessment guidelines. Simple random sampling was used to administer questionnaires to investigate demographic characteristics and public health status of residents. Data obtained were subjected to descriptive statistics and ANOVA using SPSS for Windows version 16. Results indicated elevated levels of Cadmium (Cd), Chromium $(\mathrm{Cr})$, Copper $(\mathrm{Cu})$, lead $(\mathrm{Pb})$, Manganese (Mn), Nickel (Ni) and Zinc (Zn) ranging from 0.01-1.20, 0.05-0.52, 0.80-34.80, 0.09-4.30, 0.09$8.30,0.05-3.94,0.05-19.60$ and $1.80-29.90 \mathrm{mg} \mathrm{L}^{-1}$ respectively which exceeded national recommended limits with few exceptions. Hazard Quotients (HQ) and Hazard Index (HI) of heavy metals were calculated and results greater than 1 indicate non-carcinogenic adverse health effects of the observed metals. A daily intake of water by the local residents could pose a potential health threat from long-term heavy-metal exposure. The risk assessment provided by this study can be beneficially used and applied for risk communication to avoid negative public health impact. Similarly, Water Safety quality assurance strategic plan should be developed to safeguard source, water and public health within the mining community.
\end{abstract}

Keywords: Non-Cancerous, Risk Assessment, Gold Mining, Heavy Metals Contamination, Surface Water, Groundwater, Water Safety

\section{INTRODUCTION}

Gold mining activities generates large amounts of highly soluble inorganic matter, some of which are considered toxic to life and the environment (Ramani, 2001). Generation of chemical waste as a result of mining activities occurs world-wide and may severely affect natural resources such as vegetation, water bodies and the ecosystem in general (Ramani, 2001). The chemical analysis of these pollutant concentrations in different environmental compartments (i.e., air, soil, vegetation, water, sediments) may be a significant indirect methodology for human health risk assessment. Human exposure may be considered to occur through two routes: Direct and indirect. Direct exposure is the sum of exposure to pollutants by direct pathways, such as inhalation, dermal absorption or water ingestion (USEPA, 2001) while indirect exposure occur when pollutants reach human after crossing one or several paths (Rikken and Lijzen, 2004; Zaimoglu et al., 2006).

Corresponding Author: Ayantobo O.O., Department of Water Resources Management and Agricultural-Meteorology, Federal University of Agriculture, Abeokuta (FUNAAB), Nigeria Tel: +234 8066365964 
Although some elements are essential for humans, they can be dangerous at relatively high exposure levels (Domingo, 1994; Goorzadi et al., 2009). The exposure heavy metals has been associated with a wide variety of adverse health effects, including cancer (Adeyemi et al., 2007; Ghanem and Ghannam, 2010). Other health impacts associated with ingestion of heavy metals such as Arsenic (As), leads (Pb), Manganese (Mn), Chromium $(\mathrm{Cr})$, Cadmium $(\mathrm{Cd})$, Zinc (Zn) Nickel (Ni) are many and well documented (Picado et al., 2010; Alamelumangai and DeviShree, 2012). In order to assess risks arising from ingestion of heavy metals of individual organisms, Rikken and Lijzen (2004); Hacon et al. (2010) said that it is important to consider their food habits, behavioural patterns and habitat requirements because these factors have effects on the exposure of individual organisms to heavy metals and associated risk of exposure (Hacon et al., 2010; Ndimele et al., 2011).

In Nigeria, individuals residing in mining environments have been exposed to heavy metals particularly $\mathrm{Cd}, \mathrm{Cr}, \mathrm{Cu}$, $\mathrm{Pb}, \mathrm{Mn}, \mathrm{Ni}$ and $\mathrm{Zn}$ in surface and groundwater over the last few decades and high concentrations of these heavy metals have been identified in various environmental compartments in mining communities, particularly surface and groundwater bodies (Obiri et al., 2006; Essumang, 2009). This study focuses on the Igun Ijesha in the south western region of Nigeria, within which mining activities have taken place for over a century.

Assessment of heavy metals has been carried out in the study area but no studies have attempted to quantify the risk posed to human receptors particularly among residents living in these contaminated mining areas. An assessment of the risks such contaminated surface and groundwater bodies pose to individuals living in mining communities is therefore of the essence. This study employs the USEPA risk assessment framework to evaluate the risk posed to resident adults in the mining community where gold mining activity is pervasive and longstanding. This is done by carefully evaluating doses likely to be received by individuals throughout their lifetime or at critical periods within their life cycle.

\section{MATERIALS AND METHODS}

\subsection{The Study Area}

Igun-Ijesha gold city lies between latitudes $7^{\circ} 30^{\prime}$ and $7^{\circ} 35^{\prime} \mathrm{N}$ and between longitudes $4^{\circ} 38^{\prime}$ and $4^{\circ} 42^{\prime} \mathrm{E}$ in Atakumosa West Local Government Council southwestern Nigeria (Fig. 1). The study area is a rural community of about 2,400 to 2,600 people that engage in predominantly subsistence farming alongside with cocoa plantation. Igun Ijesha is a community with many dilapidated buildings and accessible through a poorly erected bridge. Mapping of the community was done with the aid of the community members. The mapping exercise reveals local knowledge of resources, land use and settlement patterns. A Global Positioning System (GPS) was used in establishing all sampling points.

The mine locations fall within one of the six (6) classes of the Basement Complex rock that is from slightly migmatised to non-migmatised, meta-sedimentary and meta-igneous rock or simply called the Schist belt. The study area is a part of Ilesa-Ife schist belt (Ademeso et al., 2013). The belt is one of the 11 schist belts documented by TML (1996). It has two contrasting lithologies separated by NNE trending Ifewara fault zone. The west of the fault is occupied by the amphibole schist, amphibolites, talc-tremolite and pellitic rocks (TML, 1996). The eastern part has quartzite, quartz schist and amphibole schist, The gold deposit occur in this area, thus, the three Local government areas lie on the east of Ifewara fault zone. Gold occurs with ores such as: Pyrite, pyrrhotite and minor chalcopyrite, galena, sphalerite, magnetite and ilmenite. Adjacent to the gold bearing veins the host granite-gneiss has been hydrothermally altered to a sericitechlorite epidote assemblage (with also hematite and pyrite) (NMC, 1987).

\subsection{Field investigation and Water Sampling}

Igun-Ijesha area was selected for this study primarily due to the presence of gold mining activities in the community. Three surface water and three groundwater sampling points were selected and their coordinates located using a Global Positioning System GARMING 45XLS (Fig. 2).

Random sampling technique was employed in the selection of sampling sites. Sampling was done between September 2012 and February 2013. A total of thirtyeight water samples were collected from both surface and ground water samples in the study area. Water samples were collected with $1.5 \mathrm{~L}$ capacity plastic bottles which have been soaked in $70 \%$ nitric acid for 24 $\mathrm{h}$ and rinsed thoroughly with double distilled water. Samples for trace metal analyses were put into $250 \mathrm{~mL}$ plastic bottles and $2 \mathrm{~mL}$ concentrated Nitric acid added to it. Collected samples were preserved and stored in an ice-chest at a temperature of $4^{\circ} \mathrm{C}$ and transported to the laboratory for analyses. Samples were taken in separate containers for physicochemical and trace metal analysis respectively. Samples for trace metal analysis were each preserved with $0.5 \mathrm{~mL}$ of concentrated nitric acid before transporting to laboratory for analysis. During sampling, relevant information like ambient temperature $\left(31^{\circ} \mathrm{C}\right)$, date of sampling, time of sampling and season of the year were recorded. 
Ayantobo O.O. et al. / American Journal of Environmental Sciences 10 (3): 301-311, 2014

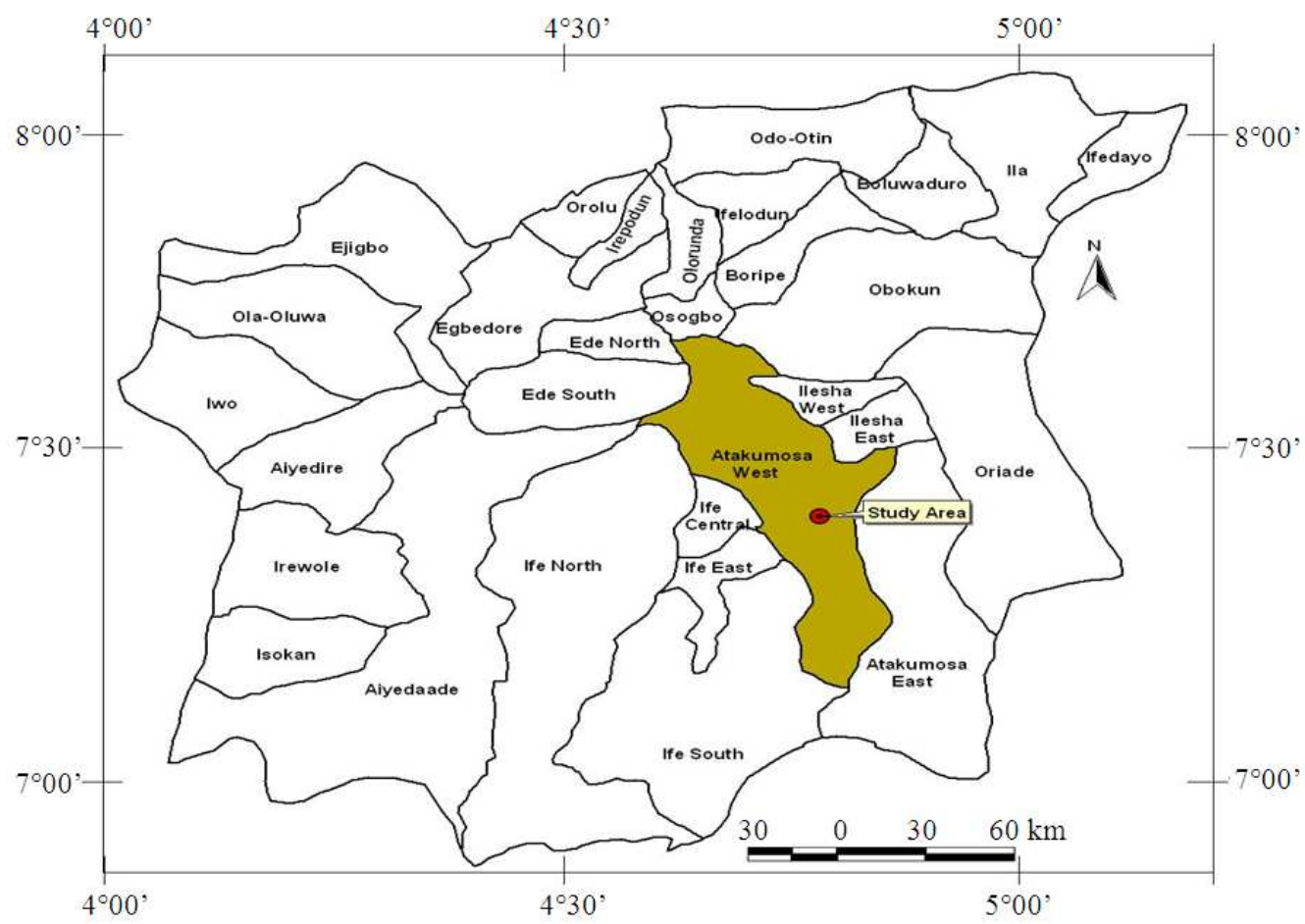

Fig. 1. Map of osun state showing the study Area

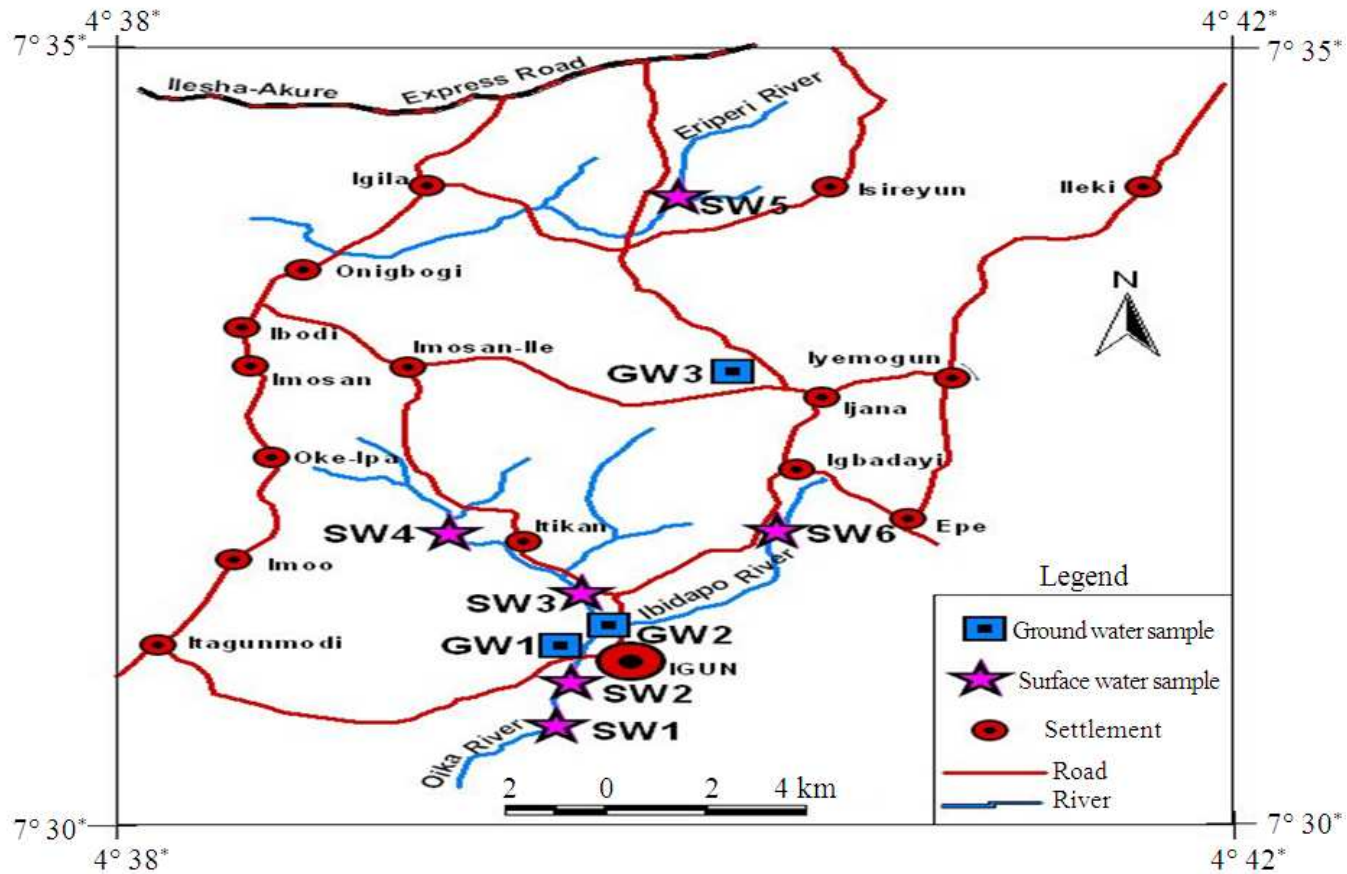

Fig. 2. Map of the study area showing the sampling locations 


\subsection{Sample Digestion and Heavy Metal Analysis}

The methods of laboratory analysis used were those specified in International analytical standards such as American Public Health Association (APHA) standard for water quality. All equipment were duly calibrated and samples were analysed in replicates. Samples for the determination of arsenic, cadmium, chromium, copper, lead, manganese, nickel and zinc were collected with $500 \mathrm{~mL}$ plastic bottles, since such metal may be adsorbed on the wall of glass bottles. About $3 \mathrm{~mL}$ of concentrated nitric acid was added and the samples were refrigerated at $4^{\circ} \mathrm{C}$ before digestion. The water samples $(100 \mathrm{~mL})$ were digested with 10 $\mathrm{mL}$ concentrated $\mathrm{HNO}_{3}$. The mixture was then heated on a hotplate for $30 \mathrm{~min}$ (USEPA, 2001). The extracts were filtered and made to $100 \mathrm{~mL}$ with distilled deionised water. The ready digests were sent to the International Institute for Tropical Agriculture (IITA) Laboratory, Ibadan and ACEME analytical laboratory, Canada for heavy metal determination using Inductively Coupled Plasma-Mass Spectrometer (ICPMS-Agilent 7500ce). The ICPMS was equipped with octopule reaction system which is effective in removing interfering species. Standards were prepared from VWR standard soluble prepared in the series of 5, 10, 20, 50 and $100 \mathrm{ppb}$. The procedures of ICPMS can be read elsewhere in Taiwo (2013).

\subsection{Questionnaire Administration}

The questionnaires would be used to find the intake rate of surface and groundwater consumed and consist the general information and personal background of the people i.e., name, the age, body weight, gender, education attainment, knowledge information and occupation and the consumption behavior (intake rate, frequency and quantity of consumption) of the local people who consumed both surface and groundwater at Igun Ijesha. A total of 65 questionnaires were administered via interviewer assisted process to voluntary participants of the community through simple random sampling (balloting).

\subsection{Human Health Risk Assessment}

This is defined as the process of estimating and quantifying the probability that an event will occur and the probable magnitude of its adverse effects with a given exposure over a specified period (NRC, 1983). It is also a process of estimating the health effects that might result from exposure to carcinogenic and noncarcinogenic chemicals (Obiri et al., 2010; USEPA, 2001). The risk assessment process as proposed by the US Environmental Protection Agency consists of four basic steps namely: (1) Hazard identification, (2) Exposure assessment, (3) Dose response/toxicity assessment and (4) Risk characterization.

\subsubsection{Hazard Identification}

This would be done through field sampling. It involves the identification of a chemical of concern and documenting its toxic effects on human beings. It also involves the characterization of potential contaminants and their relative mobilities (Kolluru et al., 1996; Paustenbach, 2002).

\subsubsection{Exposure Assessment}

This is the process of measuring or estimating the intensity, frequency and duration of human exposures to an environmental agent (Kolluru et al., 1996; USEPA, 2001; Paustenbach, 2002). In this study, non-cancer human health risk associated with exposure to some trace metals by residents of the study area in ground and surface water were determined. The intake of metals through ingestion of surface and groundwater were calculated using:

$$
\mathrm{ADD}=\frac{\mathrm{C} * \mathrm{IR} * \mathrm{ED} * \mathrm{EF}}{\mathrm{BW} * \mathrm{AT} * 365}
$$

Where:

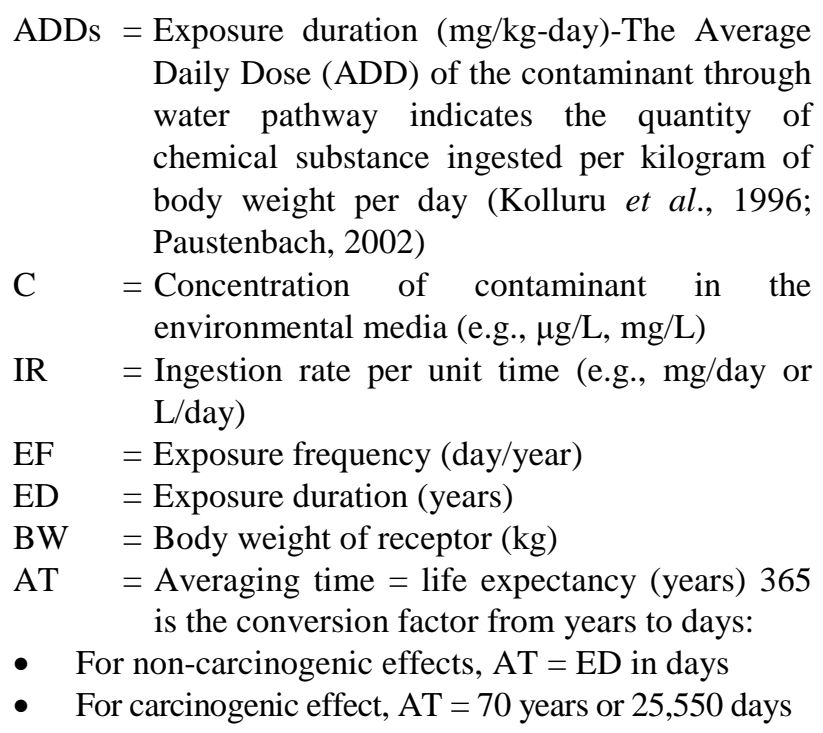




\subsubsection{Dose-Response/Toxicity Assessment}

This is a quantitative relationship that indicates a contaminants degree of toxicity to exposed species. It also involves the identification of the toxicity criteria used to evaluate human health risk associated with the chemical of concern in the study area. The amount of chemical that can be affected to human health is estimated here. In this step, the Reference Dose (RfD) will be used for non-carcinogen risk.

\subsubsection{Risk characterization}

This is the final phase of the risk assessment process. In this phase exposure and dose-response assessments are integrated to yield probabilities of effects occurring in human beings under specific exposure conditions. It can also be the incorporation of information from hazard identification, exposure assessment, toxicity assessment and risk estimation to evaluate the potential risk residents. This study followed the USEPA risk assessment guidance to evaluate the potential non-cancerous health risk of resident in the study area (USEPA, 2001). The extent of harm sustained is expressed in terms of hazard quotient as shown in Equation 2:

$$
\text { Hazard quotient }(\mathrm{HQ})=\mathrm{ADD} / \mathrm{RfD}
$$

where, ADD is the average daily dose that a resident child or adult is exposed to via contaminated water. RfD is the reference dose which is the daily dosage that enable the exposed individual to sustain this level of exposure over a long period of time without experiencing any harmful effects.

If:

- $\quad \mathrm{HQ}>1$ Adverse non-carcinogenic effects of concern

- $\mathrm{HQ}<1$ Acceptable level (no concern)

Since more than one toxicant is present, the interactions are considered. The toxic risks due to potentially hazardous substances present in the same media are assumed to be additive. The HQs may then be summed to arrive at the overall toxic risk, the hazard index (Kolluru et al., 1996; Paustenbach, 2002) Equation 3:

$$
\begin{aligned}
& H I=\sum_{i=1}^{n}(H Q) i \\
& i=1 \ldots n
\end{aligned}
$$

Where:

$\mathrm{HI}=$ The hazard index for the overall toxic risk $\mathrm{n}=$ Is the total number of metals under consideration

If $\mathrm{HI}<1.0$, the non-carcinogenic adverse effect due to this exposure pathway or chemical is assumed to be negligible.

\section{RESULTS}

\subsection{Profile of Respondents}

Residents were contacted through the use of survey techniques ranging from highly structured, randomized pre-coded questionnaires to informal, unstandardized interviews. Sixty-five people were randomly selected to participate in the survey. The questionnaires interview results are shown in Table $\mathbf{1}$ showing a response rate of $91 \%$. Majority of the respondents belongs to Yoruba ethnic group and $80 \%$ of the respondents practice Christianity as their religion. More than half (70\%) of the respondents have primary education as their highest educational level. Forty percent $(40 \%)$ of the respondent have been resident in that community for 11-20 years with about $45 \%$ of the respondent having farming as their major occupation. Majority (66\%) of the respondents said gold mining activity has a negative impact on the area and based on the responses from the respondents. No positive impact was recorded. The negative impacts include land degradation (30\%), damage to properties $(2 \%)$, damage to crops $25 \%$, health $12 \%$, security threat $(1 \%)$, environmental pollution (14\%) and the remaining $16 \%$ did not state the kind of negative problem as a resulting from gold mining.

\subsection{Hazard Identification}

The mean, ranges and standard deviations of heavy metals analysed $(\mathrm{Cd}, \mathrm{Cr}, \mathrm{Mn}, \mathrm{Cu}, \mathrm{Pb}$ and $\mathrm{Ni}$ and $\mathrm{Zn})$ in the surface and groundwater are shown in Table 2 and 3 for dry and wet seasons, respectively. With the exception of the concentration of copper in GW1, GW2 and GW3 and zinc (in GW1) ground water samples, all the parameters measured during the dry season have concentrations above the recommended limits of WHO and the Nigerian standard for drinking water quality. On the other hand, all the parameters measured during the rainy season also have elevated concentrations above the permissible limits of WHO and the Nigerian standard for drinking water except copper and zinc (SW1, SW2, SW3).

\subsection{Exposure Assessment}

The dosage of the exposure was calculated using Equation 1 and it is the excepted quantities of toxicants in the ingested water. The principal exposure factors that 
have been taken into account to carry out the risk assessment calculations are shown in Table 4 while the outcomes of the ADD estimates for $\mathrm{Cd}, \mathrm{Cr}, \mathrm{Cu}, \mathrm{Pb}, \mathrm{Mn}$, $\mathrm{Ni}$ and $\mathrm{Zn}$ are shown in Table 5 and $\mathbf{6}$ during the dry season and rainy season respectively. The average daily intakes of $\mathrm{Cu}\left(2.98 \times 10^{-2} \mathrm{mg} / \mathrm{kg}\right.$-day $), \mathrm{Mn}\left(1.60 \times 10^{-2}\right.$ $\mathrm{mg} / \mathrm{kg}$-day), $\mathrm{Ni}\left(7.75 \times 10^{-2} \mathrm{mg} / \mathrm{kg}\right.$-day $)$ and $\mathrm{Zn}$ $\left(1.60 \times 10^{-1} \mathrm{mg} / \mathrm{kg}\right.$-day) from SW1during the dry season are greater than their intake during the wet season while the intake of $\mathrm{As}, \mathrm{Cd}, \mathrm{Cr}$ and $\mathrm{Pb}$ are comparable in both season. In GW3, with the exception of $\mathrm{Pb}$ and $\mathrm{Mn}$, the average daily intakes of As $\left(1.38 \times 10^{-2} \mathrm{mg} / \mathrm{kg}\right.$-day $), \mathrm{Cd}$ $\left(2.38 \times 10^{-3} \mathrm{mg} / \mathrm{kg}\right.$-day $), \mathrm{Cr}\left(4.31 \times 10^{-1} \mathrm{mg} / \mathrm{kg}\right.$-day $)$ and $\mathrm{Cu}$ $\left(1.755 \times 10^{-2} \mathrm{mg} / \mathrm{kg}\right.$-day) during the dry season are greater than their intake during the wet season. The intake of $\mathrm{Ni}$ and $\mathrm{Zn}$ are comparable for both season.

Table 1. Characteristics of local people who consume shallow groundwater

\begin{tabular}{|c|c|c|c|c|c|}
\hline Characterization & $\begin{array}{c}\text { Number } \\
(\mathrm{n}=60)\end{array}$ & Percentage & Characterization & $\begin{array}{c}\text { Number } \\
(\mathrm{n}=60)\end{array}$ & Percentage \\
\hline Sex & & & Knowledge of gold mining & & \\
\hline Female & 14 & 23 & Aware & 55 & 91 \\
\hline Male & 46 & 77 & Not aware & 2 & 3 \\
\hline Age & & & No response & 3 & 6 \\
\hline$<20$ & 9 & 15 & Impact of gold mining & & \\
\hline $21-40$ & 30 & 50 & Negative impact & 39 & 66 \\
\hline $41-60$ & 15 & 25 & Positive impact & 11 & 18 \\
\hline$>60$ & 6 & 10 & No response & 10 & 16 \\
\hline Level of Education & & & Occupation & & \\
\hline Primary & 27 & 45 & Farmer & 26 & 43 \\
\hline Secondary & 12 & 20 & Civil servants/teaching & 2 & 3 \\
\hline Tertiary & 10 & 16 & Miners & 10 & 17 \\
\hline No formal education & 9 & 15 & Traders/self employed & 12 & 20 \\
\hline Others & 2 & 4 & Student/clergy man & 7 & 12 \\
\hline Religion & & & No response & 3 & 4 \\
\hline Christians & 48 & 80 & Income of respondent & & \\
\hline Muslims & 7 & 11 & $1,000-15,000$ & 21 & 35 \\
\hline Others & 5 & 9 & $16,000-30,000$ & 12 & 21 \\
\hline Marital status & & & $31,000-60,000$ & 7 & 11 \\
\hline Married & 42 & 70 & $>60,000$ & 7 & 11 \\
\hline Single & 15 & 25 & No response & 13 & 22 \\
\hline \multirow[t]{3}{*}{ Widow/Widowers } & 3 & 5 & Continuity of mining & & \\
\hline & & & Continue & 42 & 70 \\
\hline & & & Not continue & 18 & 30 \\
\hline
\end{tabular}

Table 2. Heavy metal content of surface and groundwater for dry season

\begin{tabular}{lllllllll}
\hline Samples & Statistics & $\mathrm{Cd}(\mathrm{mg} / \mathrm{L})$ & $\mathrm{Cr}(\mathrm{mg} / \mathrm{L})$ & $\mathrm{Cu}(\mathrm{mg} / \mathrm{L})$ & $\mathrm{Pb}(\mathrm{mg} / \mathrm{L})$ & $\mathrm{Mn}(\mathrm{mg} / \mathrm{L})$ & $\mathrm{Ni}(\mathrm{mg} / \mathrm{L})$ & $\mathrm{Zn}(\mathrm{mg} / \mathrm{L})$ \\
\hline $\mathrm{SW} 1$ & Mean \pm S.D & $0.07 \pm 0.01$ & $9.80 \pm 0.20$ & $4.20 \pm 0.10$ & $0.30 \pm 0.01$ & $0.17 \pm 0.01$ & $0.40 \pm 0.02$ & $7.30 \pm 0.10$ \\
$\left(\mathrm{~N}^{\mathrm{a}}=3\right)$ & Range & $0.06-0.08$ & $9.60-10.00$ & $4.10-4.30$ & $0.29-0.31$ & $0.16-0.18$ & $0.38-0.42$ & $7.20-7.40$ \\
$\mathrm{SW} 2$ & Mean \pm S.D & $0.180 \pm 0.02$ & $2.50 \pm 0.20$ & $3.70 \pm 0.10$ & $0.09 \pm 0.00$ & $0.10 \pm 0.01$ & $0.40 \pm 0.02$ & $6.0 \pm 0.10$ \\
$\left(\mathrm{~N}^{\mathrm{a}}=3\right)$ & Range & $0.16-0.20$ & $2.30-2.70$ & $3.60-3.80$ & $0.09-0.09$ & $0.09-0.11$ & $0.38-0.42$ & $5.90-6.10$ \\
$\mathrm{SW} 3$ & Mean \pm S.D & $0.05 \pm 0.00$ & $3.73 \pm 0.30$ & $2.38 \pm 0.94$ & $0.85 \pm 0.89$ & $1.28 \pm 1.84$ & $6.18 \pm 9.01$ & $12.80 \pm 10.23$ \\
$\left(\mathrm{~N}^{\mathrm{a}}=4\right)$ & Range & $0.05-0.05$ & $3.30-4.00$ & $1.30-3.50$ & $0.09-1.80$ & $0.05-3.94$ & $0.05-19.60$ & $5.90-27.90$ \\
$\mathrm{GW} 1$ & Mean \pm S.D & $0.050 \pm 0.00$ & $20.1 \pm 0.10$ & $1.90 \pm 0.02$ & $0.09 \pm 0.01$ & $0.06 \pm 0.01$ & $0.30 \pm 0.10$ & $1.90 \pm 0.10$ \\
$\left(\mathrm{~N}^{\mathrm{a}}=3\right)$ & Range & $0.05-0.05$ & $20.0-20.20$ & $1.88-1.92$ & $0.09-0.10$ & $0.05-0.07$ & $0.20-0.40$ & $1.80-2.00$ \\
$\mathrm{GW} 2$ & Mean \pm S.D & $0.50 \pm 0.02$ & $0.90 \pm 0.10$ & $0.10 \pm 0.01$ & $0.09 \pm 0.00$ & $0.05 \pm 0.01$ & $0.60 \pm 0.10$ & $10.50 \pm 0.30$ \\
$\left(\mathrm{~N}^{\mathrm{a}}=3\right)$ & Range & $0.48-0.52$ & $0.80-1.00$ & $0.09-0.11$ & $0.09-0.09$ & $0.05-0.06$ & $0.50-0.07$ & $10.20-10.80$ \\
$\mathrm{GW} 3$ & Mean \pm S.D & $0.19 \pm 0.01$ & $34.40 \pm 0.40$ & $1.40 \pm 0.10$ & $0.10 \pm 0.01$ & $0.05 \pm 0.00$ & $0.90 \pm 0.10$ & $29.80 \pm 0.10$ \\
$\left(\mathrm{~N}^{\mathrm{a}}=3\right)$ & Range & $0.18-0.20$ & $34.0-34.80$ & $1.30-1.50$ & $0.09-0.10$ & $0.05-0.05$ & $0.80-1.00$ & $29.70-29.90$ \\
$\mathrm{WHO}(2004)$ & & 0.003 & 0.05 & 2 & 0.01 & 0.04 & 0.07 & 3 \\
$\mathrm{SON}(2007)$ & & 0.003 & 0.05 & 1 & $\mathrm{~N} . \mathrm{A}$ & $\mathrm{N} . \mathrm{A}$ & 0.02 & 3 \\
\hline
\end{tabular}


Table 3. Heavy metal content of surface and groundwater for rainy season

\begin{tabular}{lllllllll}
\hline Samples & Statistics & $\mathrm{Cd}(\mathrm{mg} / \mathrm{L})$ & $\mathrm{Cr}(\mathrm{mg} / \mathrm{L})$ & $\mathrm{Cu}(\mathrm{mg} / \mathrm{L})$ & $\mathrm{Pb}(\mathrm{mg} / \mathrm{L})$ & $\mathrm{Mn}(\mathrm{mg} / \mathrm{L})$ & $\mathrm{Ni}(\mathrm{mg} / \mathrm{L})$ & $\mathrm{Zn}(\mathrm{mg} / \mathrm{L})$ \\
\hline $\mathrm{SW} 1$ & Mean \pm S.D & $0.05 \pm 0.00$ & $2.40 \pm 0.10$ & $0.60 \pm 0.10$ & $1.20 \pm 0.20$ & $0.06 \pm 0.01$ & $0.20 \pm 0.10$ & $0.49 \pm 0.00$ \\
$\left(\mathrm{~N}^{\mathrm{a}}=3\right)$ & Range & $0.05-0.05$ & $2.30-2.50$ & $0.50-0.70$ & $1.00-1.400$ & $0.05-0.07$ & $0.10-0.30$ & $0.49-0.49$ \\
$\mathrm{SW} 2$ & Mean \pm S.D & $0.05 \pm 0.00$ & $3.40 \pm 0.10$ & $0.60 \pm 0.10$ & $1.30 \pm 0.10$ & $2.97 \pm 0.02$ & $0.30 \pm 0.10$ & $0.49 \pm 0.00$ \\
$\left(\mathrm{~N}^{\mathrm{a}}=3\right)$ & Range & $0.05-0.05$ & $3.30-3.50$ & $0.50-0.70$ & $1.20-2.40$ & $2.95-2.99$ & $0.20-0.40$ & $0.49-0.49$ \\
$\mathrm{SW} 3$ & Mean \pm S.D & $0.05 \pm 0.00$ & 3.88 .22 & $0.78 \pm 0.28$ & $0.88 \pm 0.05$ & $0.20 \pm 0.13$ & $0.25 \pm 0.10$ & $1.15 \pm 0.58$ \\
$\left(\mathrm{~N}^{\mathrm{a}}=4\right)$ & Range & $0.05-0.05$ & $3.70-4.20$ & $0.50-1.10$ & $0.80-0.90$ & $0.10-0.37$ & $0.20-0.40$ & $0.70-2.00$ \\
$\mathrm{GW} 1$ & Mean \pm S.D & $0.05 \pm 0.00$ & $30.00 \pm 0.50$ & $0.70 \pm 0.10$ & $8.20 \pm 0.10$ & $0.12 \pm 0.01$ & $0.20 \pm 0.00$ & $3.20 \pm 0.10$ \\
$\left(\mathrm{~N}^{\mathrm{a}}=3\right)$ & Range & $0.05-0.05$ & $29.50-30.50$ & $0.60-0.80$ & $8.10-8.30$ & $0.11-0.13$ & $0.20-0.20$ & $3.10-3.30$ \\
$\mathrm{GW}$ & Mean \pm S.D & $0.05 \pm 0.00$ & $3.30 \pm 0.10$ & $0.20 \pm 0.02$ & $1.80 \pm 0.10$ & $0.05 \pm 0.00$ & $0.20 \pm 0.00$ & $3.20 \pm 0.20$ \\
$\left(\mathrm{~N}^{\mathrm{a}}=3\right)$ & Range & $0.50-0.50$ & $3.20-3.40$ & $0.18-0.22$ & $1.70-1.90$ & $0.05-0.05$ & $0.20-0.20$ & $3.00-3.40$ \\
$\mathrm{GW} 3$ & Mean \pm S.D & $0.05 \pm 0.00$ & $5.40 \pm 0.20$ & $0.30 \pm 0.10$ & $2.70 \pm 0.10$ & $0.13 \pm 0.01$ & $2.27 \pm 0.15$ & $16.60 \pm 0.10$ \\
$\left(\mathrm{~N}^{\mathrm{a}}=3\right)$ & Range & $0.05-0.05$ & $5.20-5.60$ & $0.20-0.40$ & $2.60-2.80$ & $0.12-0.14$ & $2.10-2.40$ & $16.50-16.70$ \\
WHO $(2004)$ & & 0.003 & 0.05 & 2 & 0.01 & 0.04 & 0.07 & 3 \\
SON $(2007)$ & & 0.003 & 0.05 & 1 & N.A & N.A & 0.02 & 3
\end{tabular}

SD: Standard Deviation, SW1-Oika River, SW2-Eriperi River, SW3-Justice Ibidapo River, GW1-Igun Well 1, GW2-Igun Well 2, GW3- Ijana Well

Table 4. Exposure factor for children and adult

\begin{tabular}{lllcl}
\hline Factor/parameter & Symbol & Units & Residential/agricultural & Data source \\
\hline Exposure duration & $\mathrm{ED}$ & Years & 30.0 & (USEPA, 1997) \\
Exposure frequency & $\mathrm{EF}$ & Days year & \\
Averaging time & $\mathrm{AT}$ & Years & 350.0 & (USEPA, 1997) \\
Body weight & $\mathrm{BW}$ & $\mathrm{Kg}$ & 76.5 & (KNSO, 2001) \\
Ingestion rate & $\mathrm{IR}_{\mathrm{w}}$ & $\mathrm{L} \mathrm{day}^{-1}$ & 60.0 & (ATS, 1997) \\
\hline
\end{tabular}

Table 5. The ADD values of elements with exposure pathway for dry season at Igun

\begin{tabular}{llllllll}
\hline Samples $\left(\mathrm{mg} \mathrm{kg}^{-1} \mathrm{day}^{-1}\right)$ & $\mathrm{Cd}$ & $\mathrm{Cr}$ & $\mathrm{Cu}$ & $\mathrm{Pb}$ & $\mathrm{Mn}$ & $\mathrm{Ni}$ & $\mathrm{Zn}$ \\
\hline SW1 & $5.014 \times 10^{-4}$ & $4.675 \times 10^{-2}$ & $2.983 \times 10^{-2}$ & $1.065 \times 10^{-2}$ & $1.604 \times 10^{-2}$ & $7.746 \times 10^{-2}$ & $1.604 \times 10^{-1}$ \\
GW1 & $6.267 \times 10^{-4}$ & $2.519 \times 10^{-1}$ & $2.382 \times 10^{-2}$ & $1.254 \times 10^{-3}$ & $7.521 \times 10^{-4}$ & $3.76 \times 10^{-3}$ & $2.382 \times 10^{-2}$ \\
GW2 & $6.267 \times 10^{-3}$ & $1.128 \times 10^{-2}$ & $1.254 \times 10^{-3}$ & $1.128 \times 10^{-3}$ & $6.267 \times 10^{-4}$ & $7.521 \times 10^{-3}$ & $1.316 \times 10^{-1}$ \\
GW3 & $2.382 \times 10^{-3}$ & $4.312 \times 10^{-1}$ & $1.755 \times 10^{-2}$ & $1.216 \times 10^{-3}$ & $6.267 \times 10^{-4}$ & $1.128 \times 10^{-2}$ & $3.735 \times 10^{-1}$ \\
\hline
\end{tabular}

Note: ADD via Water Pathway (mg/kg-day)

SW1: Oika River, GW1: Igun Well 1, GW2: Igun Well 2, GW3: Ijana Well

Table 6. The ADD values of element with exposure pathway for rainy season at Igun

\begin{tabular}{llllllll}
\hline S_POINT $\left(\mathrm{mg} \mathrm{kg}^{-1} \mathrm{day}^{-1}\right)$ & Cadmium & Chromium & Copper & Lead & Manganese & Nickel & Zinc \\
\hline SW1 & $5.014 \times 10^{-4}$ & $4.8635 \times 10^{-2}$ & $9.78 \times 10^{-3}$ & $1.103 \times 10^{-2}$ & $2.507 \times 10^{-3}$ & $3.134 \times 10^{-3}$ & $1.442 \times 10^{-2}$ \\
GW1 & $6.267 \times 10^{-4}$ & $3.760 \times 10^{-1}$ & $8.77 \times 10^{-3}$ & $1.028 \times 10^{-1}$ & $1.504 \times 10^{-3}$ & $2.382 \times 10^{-3}$ & $4.011 \times 10^{-2}$ \\
GW2 & $6.267 \times 10^{-4}$ & $4.137 \times 10^{-2}$ & $2.507 \times 10^{-3}$ & $2.256 \times 10^{-2}$ & $6.267 \times 10^{-4}$ & $2.382 \times 10^{-3}$ & $4.011 \times 10^{-2}$ \\
GW3 & $6.267 \times 10^{-4}$ & $6.769 \times 10^{-2}$ & $3.76 \times 10^{-3}$ & $3.384 \times 10^{-2}$ & $1.629 \times 10^{-3}$ & $2.883 \times 10^{-2}$ & $2.081 \times 10^{-1}$ \\
\hline
\end{tabular}

Note: ADD via Water Pathway (mg/kg-day)

SW1: Oika River, GW1: Igun Well 1, GW2: Igun Well 2, GW3: Ijana Well

The intake of $\mathrm{Pb}\left(1.03 \times 10^{-1} \mathrm{mg} / \mathrm{kg}\right.$-day $), \mathrm{Mn}$ $\left(1.50 \times 10^{-3} \mathrm{mg} / \mathrm{kg}\right.$-day $)$ during the wet season in GW1 was greater than their intake in dry season. The intake of $\mathrm{As}, \mathrm{Cd}, \mathrm{Cr}, \mathrm{Ni}$ and $\mathrm{Zn}$ are comparable during both seasons while the intake of $\mathrm{Cu}\left(2.38 \times 10^{-2} \mathrm{mg} / \mathrm{kg}\right.$-day $)$ is higher in dry season than in wet season. During the dry season in GW2, the intake of $\mathrm{Cd}\left(6.27 \times 10^{-2}\right.$ $\mathrm{mg} / \mathrm{kg}$-day $)$ and $\mathrm{Zn}\left(1.32 \times 10^{-2} \mathrm{mg} / \mathrm{kg}\right.$-day $)$ are high while the intake of As $\left(6.14 \times 10^{-3} \mathrm{mg} / \mathrm{kg}\right.$-day $)$ and $\mathrm{Pb}$ $\left(2.26 \times 10^{-2} \mathrm{mg} / \mathrm{kg}\right.$-day) are high during the wet season. The intake of $\mathrm{Cr}, \mathrm{Cu}, \mathrm{Mn}$ and $\mathrm{Ni}$ in both season are comparable. 


\subsection{Non-Cancer Human Risk Assessment}

Dose-response assessment was conducted in order to estimate the amount of chemical that can affect human health. The US EPA IRIS as shown in Table 7 is the most frequently cited RfD for chemicals. The toxic risk estimates are based on a comparison of actual exposure to the reference dose for the relevant chemical. The toxic risks due to potentially hazardous substances present in the same media were assumed to be additive. The HQs and the overall toxic risk, the hazard index are recorded in Table 8 and 9 respectively for dry season and wet season respectively. Generally hazard quotients estimated for the exposure to the toxicants $\mathrm{Cu}, \mathrm{Mn}, \mathrm{Ni}$ and $\mathrm{Zn}$ in this study were lower than 1, implying low risk to non-cancer diseases (Table 8 and 9). Hazard quotients estimated for the exposure to the toxicants $\mathrm{Cd}, \mathrm{Cr}$ and $\mathrm{Pb}$ were higher than 1 implying high risk to non-cancer diseases. The resulting $\mathrm{HI}$ due to potential toxicants are significantly higher than 1.0 showing a strong heavy metals ingestion.

\section{DISCUSSION}

In the study area, inhabitants were interviewed for age, sex, health status and drinking water sources information. It was noted during field work that these inhabitants were generally using contaminated surface and groundwater for their drinking and other domestic purposes. Therefore, health risks assessment for heavy metals in both surface and groundwater samples were calculated by carefully evaluating doses likely to be received by individuals throughout their lifetime or at critical periods within their life cycle (Kolluru et al., 1996; Paustenbach, 2002). The concentrations of the hazardous elements in the water sources were significantly higher than the permissible level for drinking water quality (Table 2 and 3 ) hence suggesting risks. The average exposures to these elements by residents in the form of Average daily Doses (ADD) over the period of exposure as shown in Table 5 and 6 are sufficient for making an assessment (Kolluru et al., 1996; Paustenbach, 2002).

Table 7. Reference doses of element

\begin{tabular}{lll}
\hline Substance & Oral RFD & Source $(\mathrm{Mg} / \mathrm{kg}-\mathrm{day})$ \\
\hline $\mathrm{Cd}^{\mathrm{a}}$ & $5.0 \times 10^{-4}$ & IRIS \\
$\mathrm{Cr}$ & $3.0 \times 10^{-3}$ & IRIS \\
$\mathrm{Cu}^{\mathrm{b}}$ & $3.7 \times 10^{-2}$ & IRIS \\
$\mathrm{Pb}$ & $1.4 \times 10^{-4}$ & E \\
$\mathrm{Mn}$ & $4.60 \times 10^{-2}$ & IRIS \\
$\mathrm{Ni}^{\mathrm{a}}$ & $2.0 \times 10^{-2}$ & IRIS \\
$\mathrm{Zn}^{\mathrm{a}}$ & $3.0 \times 10^{-1}$ & IRIS \\
\hline
\end{tabular}

Note: (a): US EPA IRIS database (http://www.epa.gov/iris webp/iris/index.html) (b): Decision Support System (DSS) developed in the API (American petroleum institute) (e): This value is based on the 2008 tennessee WQC (TDEC 2008) for domestic water supplies

Table 8. Hazard Indices and hazard quotients of heavy metals during dry season at Igun-Ijesha, Nigeria

\begin{tabular}{lcclllllr}
\hline Samples & Cadmium & Chromium & Copper & Lead & Manganese & Nickel & Zinc & Overall Toxic Risk (HI) \\
\hline SW1 & 1.003 & 15.585 & $8.06 \times 10^{-1}$ & 76.104 & $3.49 \times 10^{-1}$ & 3.873 & $5.35 \times 10^{-1}$ & 118.728 \\
GW1 & 1.253 & 83.982 & $6.44 \times 10^{-3}$ & 8.953 & $1.6 \times 10^{-2}$ & $1.88 \times 10^{-1}$ & $7.9 \times 10^{-2}$ & 115.590 \\
GW2 & 12.535 & 3.760 & $3.4 \times 10^{-3}$ & 8.058 & $1.4 \times 10^{-2}$ & $3.76 \times 10^{-1}$ & $4.39 \times 10^{-1}$ & 25.633 \\
GW3 & 4.763 & 143.731 & $4.74 \times 10^{-1}$ & 8.685 & $1.4 \times 10^{-2}$ & $5.64 \times 10^{-1}$ & 1.245 & 205.437 \\
\hline
\end{tabular}

SW1: Oika River, GW1: Igun Well 1, GW2: Igun Well 2, GW3: Ijana Well

Table 9. Hazard Indices and hazard quotients of heavy metals during rainy season at Igun-Ijesha, Nigeria

\begin{tabular}{lcclllllc}
\hline Samples & Cadmium & Chromium & Copper & Lead & Manganese & Nickel & Zinc & Overall Toxic Risk (HI) \\
\hline SW1 & 1.003 & 16.212 & $2.64 \times 10^{-1}$ & 78.79 & $5.4 \times 10^{-2}$ & $1.57 \times 10^{-1}$ & $4.8 \times 10^{-2}$ & 117.001 \\
GW1 & 1.253 & 125.347 & $2.37 \times 10^{-1}$ & 734.175 & $3.30 \times 10^{-2}$ & $1.19 \times 10^{-1}$ & $1.34 \times 10^{-1}$ & 886.367 \\
GW2 & 1.253 & 13.788 & $6.8 \times 10^{-2}$ & 161.16 & $1.4 \times 10^{-2}$ & $1.19 \times 0^{-1}$ & $1.34 \times 10^{-1}$ & 197.009 \\
GW3 & 1.253 & 22.562 & $6.8 \times 10^{-2}$ & 241.741 & $1.4 \times 10^{-2}$ & $1.19 \times 10^{-1}$ & $1.34 \times 10^{-1}$ & 286.364 \\
\hline
\end{tabular}

SW1: Oika River, GW1: Igun Well 1, GW2: Igun Well 2, GW3: Ijana Well 
Current study indicates the Hazard Index (HI) for the overall toxic risk of metals during the dry season to be greater than 1 . This is primarily due to high hazard quotient values recorded for $\mathrm{Cd}, \mathrm{Cr}, \mathrm{Pb}, \mathrm{Ni}$ in $\mathrm{SW} 1$ and $\mathrm{Zn}$ in GW3 respectively. As a result, the water samples have non-carcinogenic adverse effects including asthma, low intelligent quotients, mild tremor and diabetes. During the rainy season, the $\mathrm{HQ}$ values of $\mathrm{Cd}, \mathrm{Cr}$ and $\mathrm{Pb}$ are greater than 1 while the resulting $\mathrm{HI}$ values for all the elements are also significantly greater than 1 and their toxic risks due to drinking water are strong in the mining area. The HQ indices recorded for $\mathrm{Cd}, \mathrm{Cr}, \mathrm{Mn}, \mathrm{Cu}, \mathrm{Pb}$ and $\mathrm{Ni}$ and $\mathrm{Zn}$ in this study were found higher than those reported by Muhammad et al. (2011) in Kohistan region, northern Pakistan and Kavcar et al. (2009) in Turkey for drinking water. Therefore, the continuous use of water from these sources by residents could lead to health problems. From the study conducted by Obiri et al. (2010), human health risk from exposure to toxic chemicals such as $\mathrm{Cd}, \mathrm{Cr}, \mathrm{Mn}, \mathrm{Cu}, \mathrm{Pb}$ and $\mathrm{Ni}$ and $\mathrm{Zn}$ are as a result of the mining activities.

Elevated water parameters in the sampled surface and ground water indicate pollution of water resources in the study area, of which the mining activities are the major culprits. The health effects of these metals have been reported severally in published literature (Obiri et al., 2010; Lee, 2012; Joseph and Joseph, 2013). A toxicant like chromium can results into various health effects which include skin rashes, upset stomachs and ulcers, respiratory problems, kidney and liver damage, lung cancer and death (Obiri et al., 2010). Cadmium may cause lung cancer, kidney diseases, weaker bones in humans and animals, stomach irritation, vomiting and diarrhea (Golub, 2005). Lead can damage nervous connections and cause blood and brain disorders. In pregnant women, high levels of exposure to lead may cause miscarriage. Chronic, high-level exposures have been shown to reduce fertility in (Golub, 2005). Longterm exposure to nickel can cause decreased body weight, heart and liver damage and skin irritation (Obiri et al., 2010). Although humans can handle proportionally large concentrations of zinc, too much zinc as observed in SW3 can cause eminent heath problems, such as stomach cramps, skin irritations, vomiting, nausea and anemia. It can also damage the pancreas and disturb the protein metabolism. Zinc can be a dangerous to unborn and newborn children. When mothers have absorbed large concentrations of zinc, the children may be exposed to it through breast milk of their mothers (Golub, 2005; Schoeters et al., 2008; Obiri et al., 2010).
The findings of this study hold several implications for policy. Previously, most mining communities depended on surface water as drinking water sources. However, the contamination of surface water particularly via small-scale mining activities (Armah et al., 2010) made it imperative for government and other non-state stakeholders to resort to groundwater. Groundwater was considered to be a useful alternative drinking water in the mining communities. However, the findings of this study show that indiscriminate reliance on both surface and groundwater could present non-cancer human health risks to the surrounding population. Consequently, a monitoring programme is clearly advisable, while some efforts should be focused on reducing the environmental levels of $\mathrm{Cd}, \mathrm{Cr}, \mathrm{Mn}, \mathrm{Cu}, \mathrm{Pb}$ and $\mathrm{Ni}$ and $\mathrm{Zn}$ in surface and groundwater sources in the mining communities. Policy makers need to be appraised of the situation so that they can formulate regulations that make it mandatory to test sources of drinking water in mining communities on a regular basis. Where water sources have been tested, communities need to be notified about contaminant levels so that it can inform their daily decision-making regarding access to safe drinking water (Berg et al., 2007). Overall, the results indicate there is a critical need for a clearly laid out strategy to mitigate public health risks in this area.

\section{CONCLUSION}

The study evaluated the non-cancer health risks to resident from exposure to the measured heavy metals: $\mathrm{Cd}, \mathrm{Cr}, \mathrm{Cu}, \mathrm{Mn}, \mathrm{Pb}, \mathrm{Ni}$ and $\mathrm{Zn}$ in surface and groundwater within the mining community in Nigeria. Mining activities and the presence of mining facilities thus, pose a notable risk for the health of the residents living in the vicinity of the abandoned gold mine. This was in line with the situation at Igun Ijesha Municipality.

The outcomes of the risk assessment showed that the non-toxic risk of heavy metals for exposed individuals in the affected area were significantly high. The risk estimate provided by this study clearly shows that this community is at excess risk of $\mathrm{Cd}, \mathrm{Cr}, \mathrm{Mn}, \mathrm{Cu}, \mathrm{Pb}$ and $\mathrm{Ni}$ and $\mathrm{Zn}$ contamination in surface and groundwater due to ingestion. Thus, the daily intake of water by the local residents poses a potential health threat due to long-term heavy metal exposure.

The local people who generally drink surface and groundwater in this area can get non-carcinogenic effect from heavy metal contamination. In view of this, residents are at risk of contracting non-cancerous diseases such as asthma, low intelligent quotients, mild tremor and 
diabetes, among others as a result of ingestion of water from the sites. Drinking water posts a significant human health risk to the inhabitant of the mine area.

This study can be beneficially used and applied for risk communication to develop an effective risk management approach to safe guard water resources so as to prevent the adverse human health effect on local people. Also due to the dangers associated with the exposure to these toxicants, the Government could help in the provision of more potable water facilities so as to discourage inhabitants from patronizing these contaminated water sources.

\section{ACKNOWLEDGMENT}

We acknowledge the financial support given to Olusola Ayantobo by the Federal University of Agriculture, Abeokuta to carry out an extensive research work on heavy metal contamination of Water Resources in Igun Ijesha south west Nigeria during his Master of Science in Water Resources Management. The field assistance Mr. Adesuyi from the Department of Water Resources Management and Agricultural Meteorology is deeply appreciated.

\section{REFERENCES}

Ademeso, O.A., J.A. Adekoya and A. Adetunji, 2013. Further evidences of cataclasis in the ife-ilesa schist belt, Southwestern Nigeria. J. Nat. Sci. Res., 3: 50-59.

Adeyemi, O., O.B. Oloyede and A.T. Oladiji, 2007. Physicochemical and microbial characteristics of leachate-contaminated groundwater. Asian J. Biochem., 2: 343-348. DOI: 10.3923/ajb.2007.343.348

Alamelumangai, N. and J. DeviShree, 2012. Novel fuzzy technique for cancer detection in noisy breast ultrasound images. Am. J. Applied Sci., 9: 779-783. DOI: 10.3844/ajassp.2012.779.783

Armah, F.A., S. Obiri, D.O. Yawson, E.E. Onumah and G.T. Yengoh et al., 2010. Anthropogenic sources and environmentally relevant concentrations of heavy metals in surface water of a mining district in Ghana: A multivariate statistical approach. J. Environ. Sci. Health, 45: 1804-1813. DOI: 10.1080/10934529.2010.513296

ATS, 1997. Korean Agency for Technology and Standards. Berg, M., C. Stengel, T.K. Pham, H.V. Pham and M.L. Sampson et al., 2007. Magnitude of arsenic pollution in the mekong and red river deltas: Cambodia and vietnam. Sci. Total Environ., 372: 413-425. DOI: 10.1016/j.scitotenv.2006.09.010
Domingo, J.L., 1994. Metal-induced developmental toxicity in mammals: A review. J. Toxicol. Environ. Health, 42: 123-141. DOI: $10.1080 / 15287399409531868$

Essumang, D.K., 2009. Analysis and human health risk assessment of arsenic, cadmium and mercury in manta birostrisu (manta ray) caught along the ghanaian coastline. Human Ecol. Risk Assess., 15: 985-998.

Ghanem, M. and S. Ghannam, 2010. Spring water hydrochemistry along the North-South profile in the Jordan valley. Asian J. Earth Sci., 3: 122-129. DOI: 10.3923/ajes.2010.122.129

Golub, M.S., 2005. "Summary" Metals, Fertility and Reproductive Toxicity. 1st Edn., CRC press, Taylor and Francis Group, pp:. 153.

Goorzadi, M., G. Vahabzadeh, M.R. Ghanbarpour and A.R. Karbassi, 2009. Assessment of heavy metal pollution in tilehbon river sediments, Iran. J. Applied Sci., 9: 1190-1193. DOI: 10.3923/jas.2009.1190.1193

Hacon, S., C. Vega, B. Hacon, D.P.D. Carvalho and R. Almeida et al., 2010. Lead human health risk assessment case study: Cassiterite mining in the Western Brazilian Amazon, Brazil. Toxicol. Lett., 196: S66-S66. DOI: 10.1016/j.toxlet.2010.03.252

Joseph, B. and V.M. Nair, 2013. Micrornas as double edged sword in cancer. Am. J. Bioinform., 2: 1-7. DOI: 10.3844/ajbsp.2013.1.7

Kavcar, P., A. Sofuoglu and S.C. Sofuoglu, 2009. A health risk assessment for exposure to trace metals via drinking water ingestion pathway. Int. J. Hygiene Environ. Health, 212: 216-227. DOI: 10.1016/j.ijheh.2008.05.002

KNSO, 2001. Korea National Statistical Office.

Kolluru, R.V., S.M. Bartell, R.M. Pitblado and R.S. Stricoff, 1996. Risk Assessment and Management Handbook. 1st Edn., McGrow-Hill, New York.

KOWACO, 2001. Korea Water Resources Corporation.

Lee, G., 2012. Cancerous immunoglobulins and CA215: Implications in cancer immunology. Am. J. Immunol., $\quad 8$ : 101-116. DOI: 10.3844/ajisp.2012.101.116

Muhammad, S., M.T. Shah and S. Khan, 2011. Health risk assessment of heavy metals and their source apportionment in drinking water of Kohistan region, northern Pakistan. Microchemical J., 98: 334-343. DOI: 10.1016/j.microc.2011.03.003 
Ndimele, P.E., C.A. Kumolu-Johnson and M.A. Anetekhai, 2011. Spatial and temporal variations of some heavy metals in water, sediment and Chrysichthys nigrodigitatus (Lacepede, 1803) from ologe lagoon, lagos, Nigeria. Int. J. Biol. Chem., 5: 248-257. DOI: 10.3923/ijbc.2011.248.257

NMC, 1987. Mining industry of Nigeria Nigerian Mining Corporation.

NRC. 1983. Risk assessment in the Federal Government: Managing the Process. 1st Edn., National Academy Press, Washington.

Obiri, S., D.K. Dodoo, D.K. Essumang and F.A. Armah, 2010. Cancer and non-cancer risk assessment from exposure to arsenic, cadmium and copper by resident adults and children in the Obuasi Municipality, Ghana. Int. J. Human Ecol. Risk Assess., 16: 651-665. DOI: 10.1080/10807031003788907

Obiri, S., D.K. Dodoo, F. Okai-Sam and D.K. Essumang, 2006. Cancer health risk assessment of exposure to arsenic by workers of AngloGold Ashanti-Obuasi gold mine. Bull. Environ. Contam. Toxicol., 76: 195-201. DOI: 10.1007/s00128-006-0907-0

Paustenbach, D.J., 2002. Human and Ecological Risk Assessment: Theory and Practice. 1st End., John Wiley and Sons, New York.

Picado, F., A. Mendoza, S. Cuadra, G. Barmen and K. Jakobsson et al., 2010. Ecological, groundwater and human health risk assessment in a mining region of Nicaragua. Risk Anal., 30: 916-933. DOI: 10.1111/j.1539-6924.2010.01387.x

Ramani, R.V., 2001. Environmental planning in the mining industry-progress and prospects. IMM, 41: 5-9.
Rikken, M.G.J. and J.P.A. Lijzen, 2004. Update of risk assessment models for the indirect human exposure. RIVM report No 601516011/2004. National Institute for Public Health and the Environment. Bilthoven: The Netherlands.

Schoeters, G., H.E. Den, W. Dhooge, L.N. Van and M. Leijs, 2008. Endocrine disruptors and abnormalities of pubertal development. Basic Clin. Pharmacol. Toxicol., 102: 168-175. PMID: 18226071

SON, 2007. Nigerian standard for drinking water quality. Plot 1689 lome street, Wuse Zone 7, Abuja, Nigeria.

Taiwo, A.M., 2013. Receptor modeling of industrial air pollutants. PhD Thesis, University of Birmingham, UK.

TML, 1996. A pre-investment study of the primary goldmine-Odo Ijesa (primary) gold deposit report. TML.

USEPA, 1997. Exposure Factor Handbook (EPA/600/P95/002Fa)(update to Exposure Factors Handbook (EPA/600/8-89/043). Environmental Protection Agency Region 1, Washington, D.C.

USEPA, 2001. Risk Assessment Guidance for Superfund (RAGS), Volume I: Human health evaluation manual (part E, supplemental guidance for dermal risk assessment). Interim Office of Emergency and Remedial Response, Washington, DC.

WHO, 2004. WHO Guidelines for Drinking Water Quality. 3rd. Edn., World Health Organisation-Geneva.

Zaimoglu, Z., M.Y. Sucu, O.I. Davutluoglu, I. Hazir and A. Yuceer, 2006. Pollutant monitoring of a drainage canal receiving industrial and agricultural wastewater incukurova plain. J. Boil. Sci., 6: 646650. DOI: $10.3923 /$ jbs.2006.646.650 